\title{
TURBULENT KINETIC ENERGY IN FISH PASSES OF VARIOUS TYPES OF CONSTRUCTION
}

\author{
MARTA PUZDROWSKA \& TOMASZ HEESE \\ Environmental and Geodetic Sciences, Faculty of Civil Engineering, \\ Koszalin University of Technology, Poland
}

\begin{abstract}
A fish pass remains a hydraulic facility, which is to restore the migration possibility for ichthyofauna through the existing cross hydraulic structures. Except for the values of average flow velocities, the main features of flow deciding about the efficiency level of the device are values and characteristics of turbulent kinetic energy (TKE) distribution. TKE affects the power cost to be borne by fish to pass through the facility, and it affects the pace (i.e. the time) of passing through an obstacle. The main objective of research was to determine the impact of modifications in geometry of partitions in the bolt fishway channel on changes to hydraulic conditions and parameters for a water stream in a discharge channel. Relevant geometry of partitions directly improves the efficiency of objects. Bolt fishway is an object used for fish migration, where cross-partitions separating following chambers (pools) are made of cylindrical, rotary spandrel-beam elements of various height. The measurements were done for three instantaneous flow velocity components in indicated measurements sections. The analysis of the results was done for three-dimensional flow structure. The results were developed using Matlab software. The results were significantly different in comparison to the previously published ones. The differences referred to the values, as well as to the features of spatial distribution. This paper focuses on the analysis of TKE in bolt fishways, and on the comparison of that value's distribution in technical facilities of various types of construction, i.e. in pool-type fishways and in vertical slot fishways.

Keywords: fish pass, blot fishway, design of fish passes, turbulent kinetic energy, turbulence of water flow.
\end{abstract}

\section{INTRODUCTION}

Construction of efficient fish passes remains a very difficult and important task. A necessity of developing facilities of that type at water barrages results from the Water Framework Directive and from the Habitat Directive binding for the member states of the European Union. Those documents significantly consider improvement of quality for statuses and potentials of rivers and water reservoirs. However, construction of a fish pass without relevant control over its efficiency does not guarantee that quality rates for the environment would be improved. Regardless of the provisions valid in the EU, restoration of old fish migration routes is a global trend. Fragmentation of river habitats by hydraulic structures effects in decay of migrating species and, simultaneously, in high cost of environmental compensation through e.g. fish stocking.

The most popular type of facilities used for migration is a technical fish pass. Vertical slot fishways or pool-type fishways are the most often constructed ones. They are significantly easier to develop due to greater technical knowledge on the hydraulic conditions in those facilities. Technical fish passes may be developed easier on both the designing stage, as well as the investment's development stage. It affects the pace the object is being developed.

Based upon site observations it was stated that vertical slot fishways and pool-type fishways not always achieve the proper efficiency. The issue is especially related to fish species considered as so-called weak swimmers, and those are potamodromous fish. It was identified that they often wander around chambers (pools) of a fish pass or they cannot pass through the partition, thus they gather directly underneath the slot, inside the facility [1]. It 
not only results in limitation of the possibility to migrate for weak swimmers, but what is most important, it significantly increases the migration time. It may result in fish reaching the spawning site too late.

Due to small efficiency of passing through fish passes by potamodromous fish, in case of previously known fish passes, research was undertaken to examine a different partition geometry for the technical facility. The examined type of fish pass is a bolt fishway. The obtained results were compared with data taken from publications related to facilities of another structure type. It is to establish the reasons for weaker migration of potamodromous fish. However, it also is to establish mechanisms for distribution of the most important except for velocity - migration barrier, which is a value of turbulent kinetic energy (TKE).

\section{MODELS AND METHODS}

\subsection{Description of the models}

The name of the structure (bolt fishway) is associated with the applied cross-barriers in the facility's channel. Cross-partitions are made of linearly placed cylindrical bolt elements of various height, thus separating consecutive chambers (pools) of the fish pass. The cylinders are assembled on spindles and they may be rotated.

Cross-section of bolt elements - getting narrower with height - allows for forming diverse flow conditions in the fish pass just on the object's use stage.

The research was done based upon 2 laboratory models - A and B. A prototype of the solution is model A, which reflects basic assumptions for the construction. Model B remains a modification of model $\mathrm{A}$, which includes moving of one bolt, and therefore moving the axis of partition for the main slot and for two smaller spillway slots.

Basic assumptions on bolt fish pass's geometry (in the actual scale) are as follows: channel width $4 \mathrm{~m}$, length of a single chamber (pool) $6 \mathrm{~m}$, long drop of the bottom $2 \%$. The designed actual flow was $2.14 \mathrm{~m}^{3} / \mathrm{s}$, at maximum filling of the chambers to a height of $1.10 \mathrm{~m}$. Width of the main migration slot is $0.8 \mathrm{~m}$. On the other hand, bolt elements have the following dimensions: no. 1 - height $1.3 \mathrm{~m}$; no. 2 - height $0.6 \mathrm{~m}$; no. 3 - height $0.8 \mathrm{~m}$. The cross-section of all elements is elliptic and has the following diameter $0.64 \mathrm{~m}$ (semi-major axis) and $0.52 \mathrm{~m}$ (semi-minor axis). Bolt elements are assembled on steel spindles, and this is why the bolt element may be rotated and therefore the hydraulic conditions in the facility may be regulated on the object's use stage.

Models A and B were developed in a linear scale of 1:5, for which the remaining parameters are as follows: width $0.8 \mathrm{~m}$ (inside), and length of a single chamber $1.20 \mathrm{~m}$ (from the axis to the axis of partition). The model was developed as a series of eight chambers. Drop of the bottom was $2.0 \%$. Maximum filling of the model's chambers was $22 \mathrm{~cm}$, and minimum one was $20 \mathrm{~cm}$. Bolt elements had the following parameters (numbering of bolt elements in accordance with Fig. 1): no. 1 - height $26 \mathrm{~cm}$; no. 2 - height $12 \mathrm{~cm}$; no. 3 height $16 \mathrm{~cm}$. The cross dimension was reduced to $12.8 \mathrm{~cm}$ for the longer diameter, and to $10.4 \mathrm{~cm}$ for the shorter diameter. The measuring chamber was placed in a central part of the model. The test flow corresponding with the flow probability criterion according to Froude was $38 \mathrm{l} / \mathrm{s}$.

For the purpose of tests three-dimensional acoustic Doppler velocimeter SonTek $16 \mathrm{MHz}$ MicroADV was applied. Eleven sections were developed during the research, 18 measurement vertical lines each. Due to the fact that a distance between the measurement cell and the probe's head is $5 \mathrm{~cm}$, there were huge difficulties in measuring final three spots placed at a level of $0 \mathrm{~cm}, 2 \mathrm{~cm}$, and $4 \mathrm{~cm}$ underneath the surface of water. 


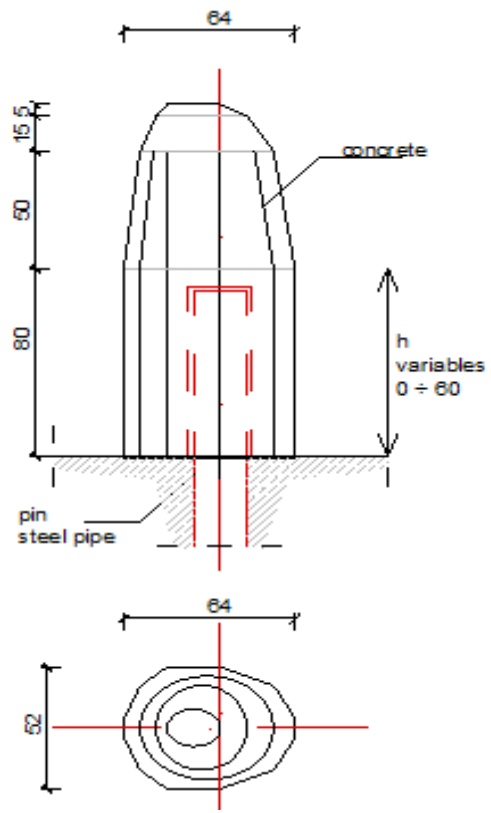

(a)

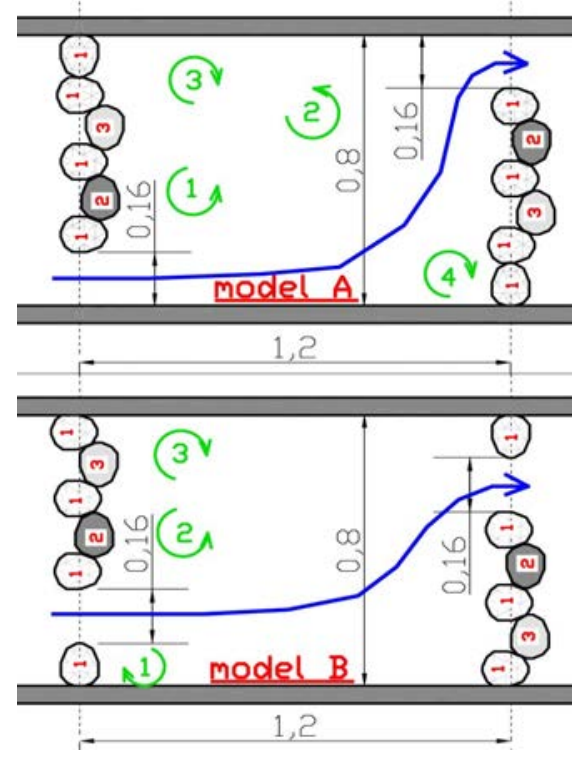

(b)

Figure 1: Laboratory models. (a) Bolt element (cm); (b) Model A and B construction arrangement - dimensions of bolt elements quoted below. Note: location and direction of rotation for huge whirl structures is marked in green - marked with numbers from 1 to 4 .

Due to requirements of Matlab, which was used to develop the results, one has decided to additionally measure those spots. Spots on a level of $4 \mathrm{~cm}$ underneath the surface of water (16 cm above the bottom) were measured by placement of the probe at an angle. It was enabled by a rotary handle fixing the probe. Then the flow was increased and measurement of the same spot was repeated, but this time at the vertical alignment of the probe. After analyzing the results it was established that the difference in values of average directional velocities and in their standard deviations is not more than $3 \%$ of the value. Therefore, it was assumed during the measurements that geometry of the bolt affects the flow parameters more than the distance between the measurement spot and the surface of water. Spots placed on a depth of $0 \mathrm{~cm}$ and $2 \mathrm{~cm}$ below the water table at filling of up to $22 \mathrm{~cm}$ were additionally measured at the increased flow.

It is important that the increase of flow (up to a height of $25 \mathrm{~cm}$ ) did not cause flooding of the bolt chamber (height of bolt elements is $26 \mathrm{~cm}$ ). This is why the stream's flow character in the model was kept. Active opening in the bolt's section was not modified at the additionally measured spots, because those levels were placed above the highest parapet of additional spillway slots.

The research was done at sections with the following spacing (18 measurement vertical lines at each section): section $\mathrm{r}-0.00 \mathrm{~m}$ (bolt at the inlet to the measurement chamber); section $\mathrm{a}-0.15 \mathrm{~m}$; section $\mathrm{b}-0.25 \mathrm{~m}$; section $\mathrm{bb}-0.35 \mathrm{~m}$; section $\mathrm{c}-0.5 \mathrm{~m}$; section $\mathrm{cc}-$ $0.65 \mathrm{~m}$; section d $-0.85 \mathrm{~m}$; section dd $-1.00 \mathrm{~m}$; section ddd $-1.05 \mathrm{~m}$; section ee $-1.10 \mathrm{~m}$; section $\mathrm{rr}-1.20 \mathrm{~m}$. 


\subsection{Methods of analysis}

TKE (sometimes marked as "k") remains one of the most important characteristics for the turbulent flow. As proved by the observations, its value highly affects behavior of fish in fish passes. From the physical point of view it is a kinetic energy of a liquid's volume unit associated with pulsatory motion [2]. Therefore, a mathematic formula for TKE is as follows [3]:

$$
T K E=0.5\left[\overline{v_{x}^{\prime 2}}+\overline{v_{y}^{\prime 2}}+\overline{v_{z}^{\prime 2}}\right],
$$

where $\overline{v_{x}^{\prime 2}}$ is the standard deviation for fluctuation of directional flow velocity.

The TKE grossing-up factor in the model amounted to 5.08. The research was developed using Matlab software.

\section{RESULTS AND DISCUSSION}

\subsection{Results for bolt fishways}

The research presented in this paper presents horizontal (parallel to the bottom) projection of flow parameters. In both cases A and B, the sections are placed just below the parapet of the biggest additional slot. They are placed on level no. 5, i.e. $10-11 \mathrm{~cm}$ over the model's bottom (50-55 cm above the bottom, considering the actual scale). The results shown in Figs 2 and 3 present the outcome for the actual scale of the object (for $\mathrm{Q}=2.14 \mathrm{~m}^{3} / \mathrm{s}$ ).

TKE distribution presented in Figs 2 and 3 show that the area of the main flow corresponds with quite low TKE value. Over the entire length of the main stream's flow area TKE does not exceed the value of $0.1 \mathrm{~m}^{2} / \mathrm{s}^{2}$, for both of the models. The increase of TKE values was noted especially in whirl zones, at the boundary between the top flow area and the whirl zones. Induction of energy production in those areas remains a results of mutual impact of whirl structures on each other. The impact mainly results from a specific three-dimensional flow structure, which is highly different in each of the discussed cases.

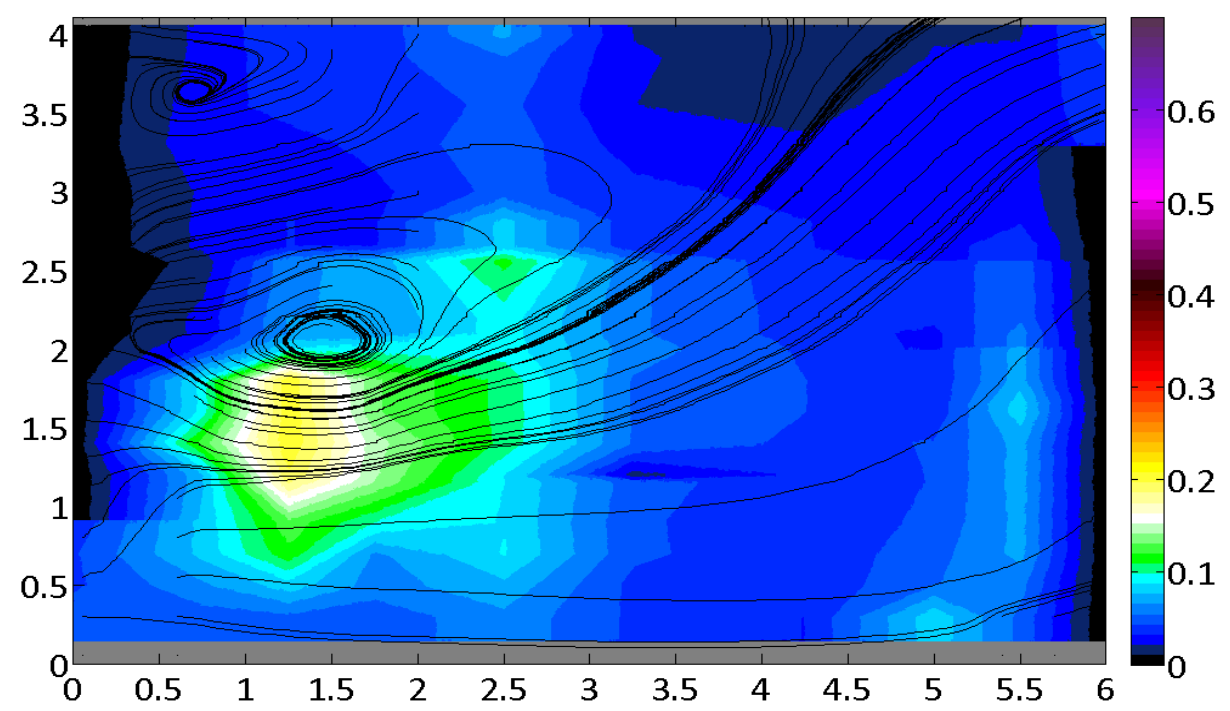

Figure 2: Characteristic section for TKE $\left(\mathrm{m}^{2} / \mathrm{s}^{2}\right)-$ model A [4]. 


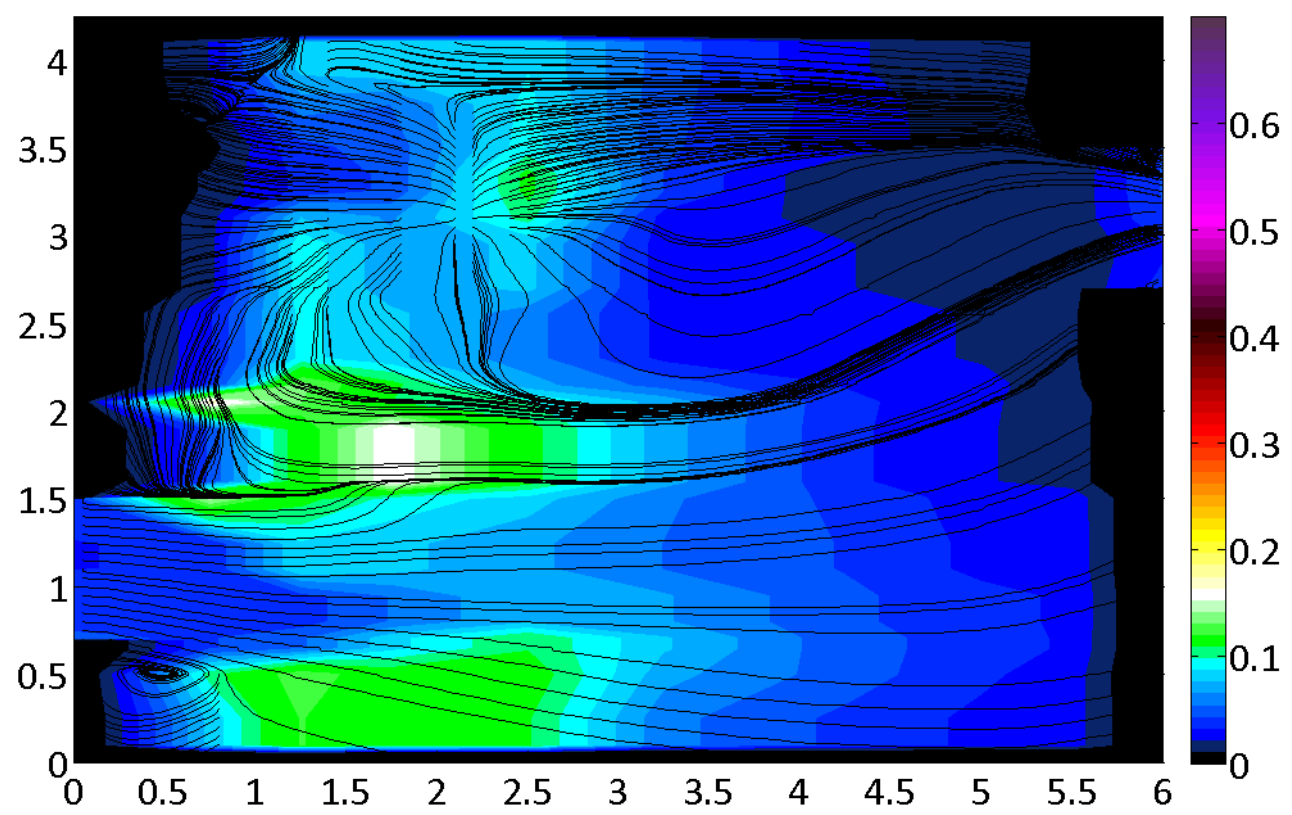

Figure 3: Characteristic section for TKE $\left(\mathrm{m}^{2} / \mathrm{s}^{2}\right)-$ model B [4].

A detailed description of the spatial flow structure, TKE features, and changes in the distribution mechanism for that parameter shall be described in another paper.

\subsection{Results for fish passes on the technical design - confrontation}

In order to verify features of the flow in the bolt fishway - in reference to other types of the structure - we have analyzed several publications [1], [4]-[14]. Results of TKE tests obtained for the bolt structure are diametrically different from the ones previously known from the publications developed for other types of fish passes.

The first and the most important difference is the mechanism of spatial TKE distribution. Publications referring to technical fishways with pool-type and slot structure prove that the greatest TKE values in the chamber are focused around the outlet from the slot or from the migration hole.

One may generally see that the level values are taken by TKE in the area of the main water stream's flow. The whirl area contains areas, where TKE production is being noticeably reduced.

Domination of extreme TKE values in the area of the main flow remains a feature of both types of structures known before, i.e. pool-type structure and slot structure.

The other difference is the volume of obtained parameter. A direct comparison of TKE values using distributions given in various scientific articles is very difficult. There are two reasons for that: diversified scale of values for presented objects and normalization of TKE values applied by scientists.

Objects of major scale were compared to our model in the actual scale. Laboratory models remained a greater challenge, as they included much diversified flow values. At inclusion of 


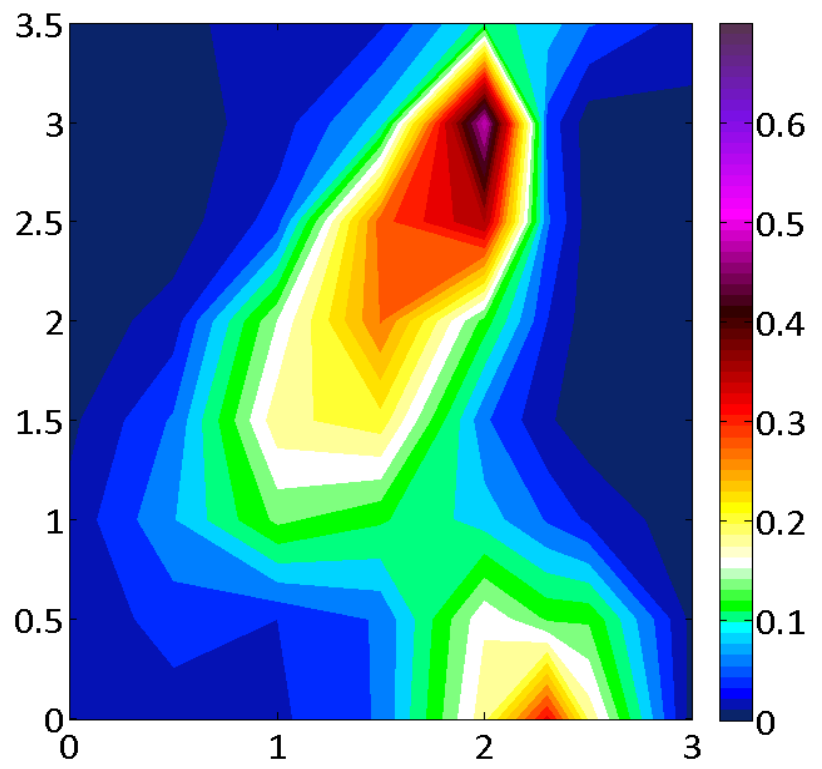

Figure 4: TKE distribution in a vertical slot fishway $\left(\mathrm{m}^{2} / \mathrm{s}^{2}\right)$ (based on [5]).

variability of geometry features (e.g. in pool-type fishways) hydraulic conditions were often not corresponding with each other at all. The biggest issue was a huge difference of scale for filling of the facilities, and especially in case of pool-type structures. Therefore, at the analysis of TKE values, we decided to recalculate our model to a model comparable in terms of hydraulic parameters for a similar flow volume in the fish pass. This is why, for the purpose of rough comparison of our results with data taken from the publications, we projected the results of other research units, and - using Matlab software - recalculated the normalized TKE values to form defined in eqn (1).

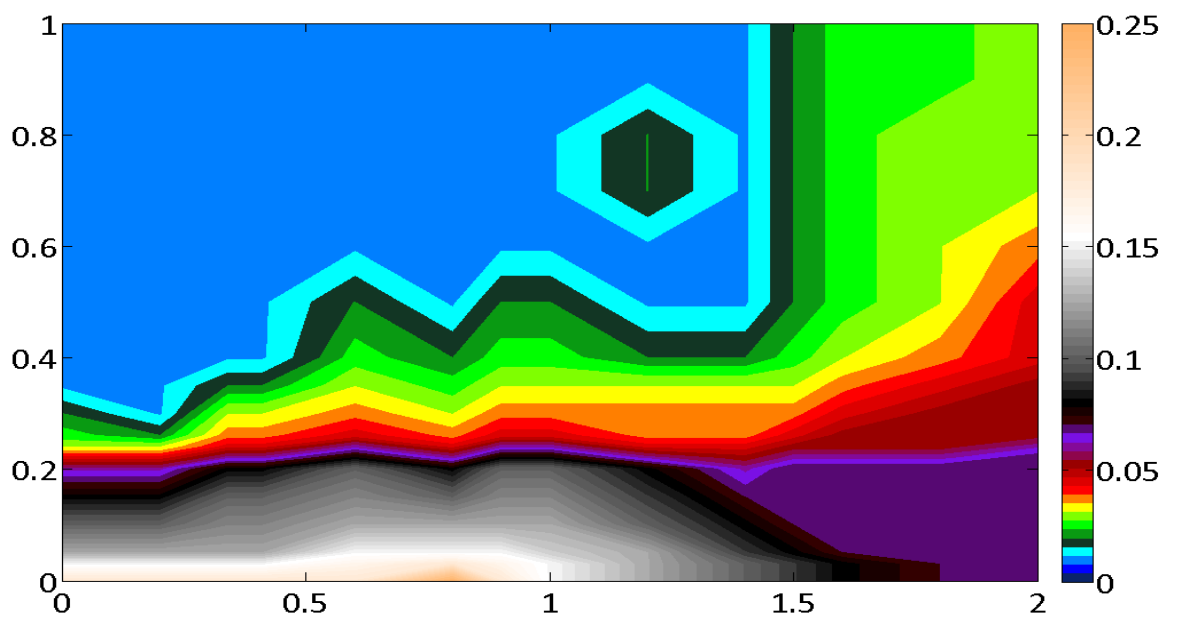

Figure 5: Distribution of TKE in pool-type fishway $\left(\mathrm{m}^{2} / \mathrm{s}^{2}\right)[6]$. 
This complicated and time-consuming task provided very interesting effects. It came out that the bolt fishway has a completely different distribution of TKE values in chambers. Furthermore, pool-type structures and slot structures - made in a similar scale - had significantly higher TKE values. The difference was noticeable in the area of the main stream's flow mainly.

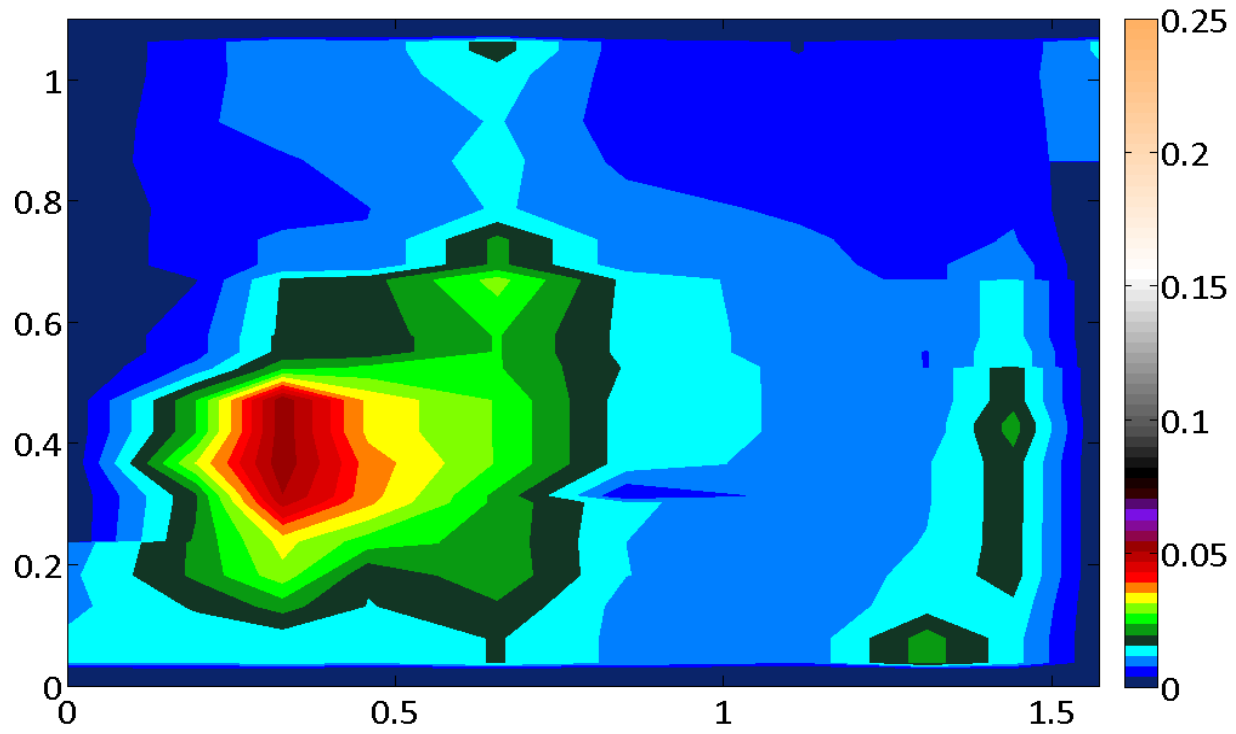

Figure 6: Distribution of TKE in bolt fishway - model A $\left(\mathrm{m}^{2} / \mathrm{s}^{2}\right)$. Scale of the model according to [6].

\subsection{Discussion}

A significant stage of our works on that issue was establishing reasons for such a huge differences in TKE values in compared structures. As a result of the analyses a reason for a different behavior of the main stream was identified. The main issue was a diversified potential of the flow stream [4]. It turns out that bolt fishways have a stream with much bigger potential than the one recorded in fishways of another type.

We applied those assumptions to provide a series of simulations to verify how is the main stream's potential reflected in TKE values obtained just downstream of the outlet from the main migration slot in the facility. The analyses done allowed us to establish an approximate formula for $\sqrt{T K E}$ value. A basis of the formula is a relation determined in a formula (M). It was marked in orange on the diagram. The final formula $(\mathrm{MH})$ was established through attempts to reach the expected value by the obtained parameter (M), i.e. $\sqrt{T K E}$. The most important achievement is the fact that the formula allows for forecasting of the TKE value in the central part of the outflow (just downstream of the slot) of the main stream in the fishway. It is feasible at application of data at the designers' disposal, without performance of laboratory tests. Those mainly are data related to the facility's geometry and basic hydraulic information available just at the preparation stage for the project. Examples used in the analyses are developed using various scales and various types of object structure. The formula reduces the issue of the object's scale. Some deviations of the estimated TKE value 
are obviously noticeable. However, one shall take into account the fact that the analyzed research was done by scientists in measurement spots located at various levels in reference to the fishway's bottom.

$$
\begin{gathered}
M=\left(\frac{1}{n}\right)\left[\left(\frac{\mathrm{Q}}{L \cdot B \cdot h}\right)^{2}\left(\frac{l_{o}}{b_{o} \cdot h_{o}}\right) h^{2} \Delta H\right]^{0,5}\left(\frac{h}{\Delta H}\right)\left(\frac{h}{h_{o}}\right), \\
M H=\left(\frac{1}{n}\right)\left[\left(\frac{\mathrm{Q}}{L \cdot B \cdot h}\right)^{2}\left(\frac{l_{o}}{b_{o} \cdot h_{o}}\right) h^{2} \Delta H\right]^{0,5}\left(\frac{h}{\Delta H}\right)^{1,1}\left(\frac{h}{h_{o}}\right)^{1,5}\left(\frac{h_{o u}}{h_{o}}\right)^{4},
\end{gathered}
$$

where

- $\quad n$ - number of migration slots (-).

- $\mathrm{Q}$ - consumption / flow in the fish pass $\left(\mathrm{m}^{3} / \mathrm{s}\right)$.

- $\quad L$ - length of the fishway's chamber (m).

- $\quad B$ - width of the fishway's chamber $(\mathrm{m})$.

- $h$ - average filling of the fishway's chamber $(\mathrm{m})$.

- $\quad l_{o}$ - longitudinal dimension of the slot / migration hole (e.g. thickness of the wall) (m).

- $\quad b_{o}$ - width of the slot / migration hole (m).

- $h_{o}$ - height of the migration hole / minimum height of the slot's flooding downstream of the outlet from the migration slot $(\mathrm{m})$.

- $\Delta H$ - hydraulic drop for a single chamber (m). Calculated as: $\Delta H=i[\%] \cdot L$.

- $\quad i$ - long drop of the fishway's bottom (\%).

- $h_{o u}$-effective water gauge level affecting the slot from the top of the fishway's channel (m). Calculated as: $h_{o u}=h_{o}+\Delta H$. For the hole of the pool-type fishway $h_{o u}=h_{o}$.

The purpose of the test done was to achieve the value of $\sqrt{T K E}$ by MH function. As it can be seen on Fig. 7, there is no full covering, when the MH function gets close to the value of VTKE. Noticeable deviations may however be justified. The most important difference between the measured TKE value and the value resulting from the formula is visible for case of publications with black and white diagrams were printed, what made the task more difficult [13]. Furthermore, in some case one may notice that the function provides slightly higher TKE value than the ones resulting from a direct measurement [7]. The issue may also refer to the proper location of measuring spots, and - to be honest - to not placing the probe in the area of higher TKE values in the model. In reality the flow in fishways is threedimensional what proves how difficult this task is, and therefore the issue of proper placement of measuring spots remains a very complicated task.

\section{CONCLUSIONS}

Based upon the analyses done one may unequivocally state that the bolt fishway is a structure, which has the highest stream flow potential among the fish passes of technical type. It provides smaller - compared to other technical fishways - TKE values obtained in the area of the main flow at the inlet to the chamber. As a consequence, it is the most relevant facility for fish migration, including weak swimmers, i.e. potamodromous fish.

As reasons for diversification of the stream's potential within the fishway's channel were identified, a formula for an approximate TKE value - which may be expected in the central part of the slot just downstream of the stream's outflow from the migration slot - was developed. The formula allows for obtaining (approximate) information on the estimated TKE value on the stage of designing. It shall significantly facilitate the work and accelerate implementation of a potential investment. 


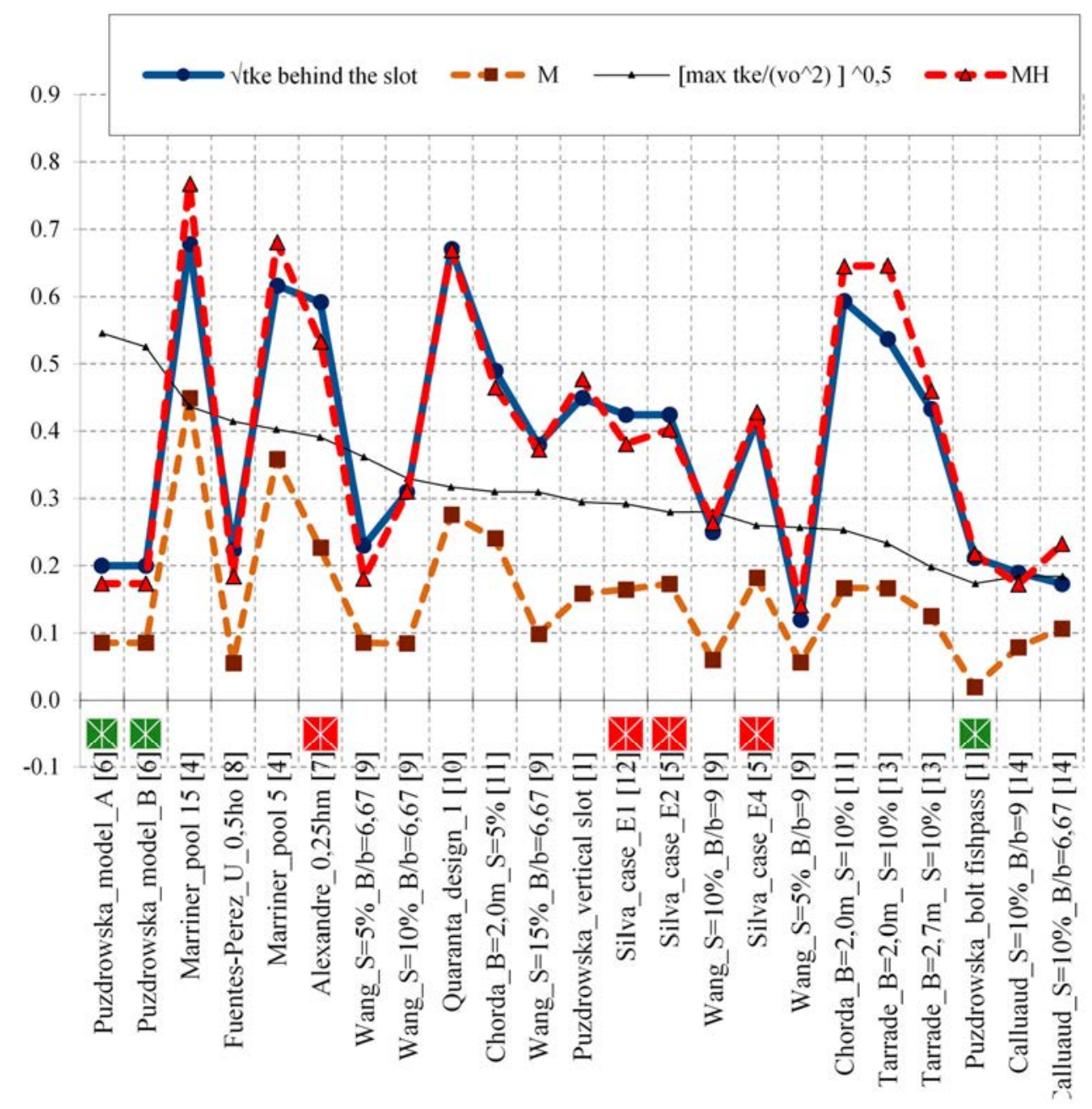

Figure 7: Diagram on the relation between the value of TKE and eqns (2) and (3).

\section{REFERENCES}

[1] Puzdrowska, M., Application of numerical methods in the design and analysis of fish pass efficiency. Technical Transactions. Environment Engineering, 110(1-Ś), pp. 99109, 2013.

[2] Gryboś, R., Podstawy mechaniki płynów, Wydawnictwo Naukowe PWN, Warsaw, Poland, 1998.

[3] Nezu, I. \& Nakawaga, I., Turbulence in open-channel flows. IAHR Monograph Series, Balkema, Rotterdam, pp. 1-281, 1993.

[4] Puzdrowska, M. \& Heese, T., Detailed research on the turbulent kinetic energy's distribution in fishways in reference to the bolt fishway. Fluids, 4(2), p. 64, 2019. DOI: 10.3390/fluids4020064. 
[5] Marriner, B.A., Baki, A.B.M., Zhu, D.Z., Cooke, S.J. \& Katopodis, C., The hydraulics of a vertical slot fishway: A case study on the multi-species Vianney-Legendre fishway in Quebec, Canada. Ecological Engineering, 90(2016), pp. 190-202, 2016.

[6] Silva, A.T., Katopodis, C., Santos, J.M., Ferreira, M.T. \& Pinheiro, A.N., Cyprinid swimming behaviour in response to turbulent flow. Ecological Engineering, 44(2012), pp. 314-328, 2012.

[7] Alexandre, C.M. et al., Use of electromyogram telemetry to assess the behavior of the Iberian barbell (Luciobarbus bocagei Steindachner, 1864) in a pool-type fishway. Ecological Engineering, 51(2013), pp. 191-202, 2013.

[8] Fuentes-Pérez, J.F. et al., Hydraulics of vertical-slot fishways: Nonuniform profiles. $J$. Hydraul. Eng., 145(2), 06018020, 2019.

[9] Wang, R.W., David, L. \& Larinier, M., Contribution of experimental fluid mechanics to the design of vertical slot fish passes. Knowledge and Management of Aquatic Ecosystems, 396, 2010.

[10] Quaranta, E., Comoglio, C., Katopodis, C. \& Revelli, R., Numerical simulations of flow field in vertical slot fishways. XXXV Convegno Nazionale di Idraulica $e$ Costruzioni Idrauliche, Bologna, 14-16 September 2016.

[11] Chorda, J., Maubourguet, M.M., Roux, H., Larinier, M., Tarrade, L. \& David, L., Twodimensional free surface flow numerical model for vertical slot fishways. Journal of Hydraulic Research, 48(2), pp. 141-151, 2010.

[12] Silva, A.T., Santos, J.M., Ferreira, M.T., Pinheiro, A.N. \& Katopodis C., Passage efficiency of offset and straight orifices for upstream movements of Iberian barbel in a pool-type fishway. River Research and Applications, 28, pp. 529-542, 2012. DOI: 10.1002/rra.1465.

[13] Tarrade, L., Texier, A., David, L. \& Larinier, M., Topologies and measurements of turbulent flow in vertical slot fishways. Hydrobiologia, 609, pp. 177-188, 2008.

[14] Calluaud, D., Pineau, G., Texier, A. \& David, L., Estimation of the turbulent features of flow in vertical slot fishway: improvements on fishway design criteria. 3rd IAHR Europe Congress, Book of Proceedings, Porto, Portugal, 2014. 